\title{
Broiler Farmers' Behavior in Administering Antibiotic and Types of Antibiotic Content in Commercial Feed (A Case Study)
}

\author{
Yulia Wasnaeni ${ }^{1)},{\text { Achmad }|q b a|^{2)}}^{2}$ and Ismoyowati ${ }^{\left.3\right|^{*}}$ \\ ${ }^{1)}$ Alumni of Environmental Study Department, Graduate School, Jenderal Soedirman University, Purwokerto, Indonesia \\ ${ }^{2)}$ Faculty of Agriculture, Jenderal Soedirman University, Purwokerto, Indonesia \\ ${ }^{3)}$ Faculty of Animal Science, Jenderal Soedirman University, Purwokerto, Indonesia \\ "Corresponding author email: moy.moyowati@gmail.com
}

\begin{abstract}
The objective of this research was to describe broiler farmers' behavior including knowledge level, attitude, antibiotic practice and analysis of the antibiotic content in broiler chicken commercial feed. Survey method was conducted with purposive and random sampling, applying Nomogram Harry King to determine total sample. Ninety-six farmers met the sampling criteria, comprising 33 respondent farmers along with survey and feed sampling in each farmer. Interview and questioner result on knowledge level and farmers' attitude and observation on farmers practice in administering antibiotic were subject to description in data tabulation. Laboratory analysis result using Bioassay method on antibiotic content in feed was described in data tabulation. Broiler farmers in Pengadegan municipality, Purbalingga Regency generally showed moderate knowledge level (60\% above average, $40 \%$ under average). Farmers with supportive attitude on good antibiotic administration was $48.48 \%$, while those less supportive reached $51.52 \%$. Farmers' level of obedience in proper antibiotic practices was only $21.21 \%$, almost half $(45.45 \%)$ defiled the proper antibiotic administration. Most farmers (96.97\%) used commercial feed containing AGP (Antibiotic Growth Promoter) not recommended by government, namely penicillin, kanamycin, erythromycin andoxytetracycline. Farmer administered overdosed antibiotic as growth booster, anti-stress, disease control and medication. Research concluded that most broiler farmers violated the rules of antibiotic practices, in which overdosed content was administered to stimulate growth, anti-stress, disease control and medication. Antibiotic as growth booster was contained in feed. Commercial broiler feed (complete feed) contained four types of antibiotic, namely penicillin, kanamycin, erythromycin andoxytetracycline.
\end{abstract}

Key words: Farmer practice, broiler, antibiotics

Abstrak. Tujuan penelitian ini adalah menggambarkan perilaku peternak broiler mencakup tingkat pengetahuan, sikap, penggunaan antibiotik, dan analisa kadar antibiotik pada pakan komersial broiler. Metode survey dilakukan dengan sampling acak bertujuan dengan Nomogram Harry King untuk menentukan total sampel. Sembilan puluh enam peternak memenuhi kriteria, mencakup 33 responden peternak dengan survey dan sampel pakan untuk setiap peternak. Hasil interview dan kuesioner tentang tingkat pengetahuan dan perilaku peternak dalam menggunakan antibiotik dideskripsikan dalam tabulasi data. Hasil analisa laboratorium menggunakan metode Bioassay untuk kandungan antibiotik dalam pakan disajikan pada tabulasi data. Peternak broiler di Kecamatan Pengadegan, Kabupaten Purbalingga umumnya memiliki tingkat pengetahuan sedang ( $60 \%$ diatas rata-rata, $40 \%$ dibawah rata-rata). Peternak dengan sikap mendukung penggunaan antibiotik sebanyak $48,48 \%$, sedangkan yang kurang mendukung sebanyak $51,52 \%$. Tingkat kepatuhan peternak pada penggunaan antibiotik yang benar hanya $21,21 \%$, hampir separuh $(45,45 \%)$ tidak mematuhi penggunaan antibiotik yang benar. Sebagian peternak $(96,97 \%)$ menggunakan pakan komersial yang mengandung AGP (Antibiotic Growth Promotor) yang tidak direkomendasikan oleh pemerintah, yaitu penisilin, kanamisin, eritromisin andoksitetrasiklin. Peternak menggunakan antibiotik melebihi dosis untuk memacu pertumbuhan, sebagai anti stres, mengendalikan penyakit dan pengobatan. Penelitian menyimpulkan bahwa sebagian besar peternak broiler melanggar aturan penggunaan antibiotik, dimana kandungan yang overdosis digunakan untuk memacu pertumbuhan, sebagai anti stres, mengendalikan penyakit, dan pengobatan. Antibiotik sebagai pemacu pertumbuhan terkandung pada pakan. Pakan broiler komersial (complete feed) mengandung empat jenis antibiotik yaitu penisilin, kanamisin, eritromisin andoksitetrasiklin.

Kata kunci: perilaku peternak, broiler, antibiotik 


\section{Introduction}

Breeding development faces demand not only on improving food quantity but also supplying quality animal food within ASUH/aman, sehat, utuh, halal (Safe, Healthy, Whole and Halal) criteria. Food safety definition according to Peraturan Pemerintah (Government Regulation) No. 28 Year 2004 is condition and effort needed to keep food from biological (microbiological) and chemical contaminants as well as other substances that might corrupt, disadvantage and harm human health. Breeding development that will guarantee sustainability and living quality of present and future generation is environmentbased breeding development.

Poultry meat is a sound protein source containing complete and balanced essential amino acids. Broiler in no time has become strategic poultry business commodity and replaced other animal husbandry for meat supply especially beef. Broiler production in 2011 reached $63.3 \%$ of total national meat production (Directorate General of Animal Husbandry and Health, 2011). Broiler high demand stimulates the rapid development in broiler industry. Antibiotic administration and cultivation management are common in stabilizing optimum production of broiler production. Besides controlling infectious disease, antibiotic also boost growth known as AGP (Antibiotic Growth Promoter). There has been antibiotic euphoria for the last decades, estimated from a half antibiotic sold worldwide registered for feed. Antibiotic overuse in poultry industry greatly contributes to increasing global resistance to antibiotic and drives such a great concern that European Union banned antibiotic as growth booster in 2006 (WSPA, 2010).

Violating proper antibiotic practice in poultry farming can risk the society, inducing antibiotic residue in meat due to improper dosage and/or ignorance to drug expiry date
(Soetisna, 2010). There have been many reports dealing with various antibiotic residue in chicken meat and liver and the danger it causes. The results of Four Plate Test (FPT) revealed that up to $17.5 \%$ of the samples were contaminated with the antibiotic. The ELISA assay showed that out of 28 positive samples in FPT, 22 liver, 21 kidney and 14 muscle samples were positive for chloramphenicol. ELISA analyses demonstrated that the minimum and maximum levels of 0.54 and $155.2 \mathrm{ng} / \mathrm{g}$ were detected in the kidney and liver, respectively (Tajik et al., 2010).While survey in Jabodetabek reported 855 broiler meat contained antibiotic residue and $37 \%$ broiler pate contained antibiotic residue from tilosin, penicillin, oxytetracycline and kanamycin (Indonesian Nutrition Network, 2004). West Java Survey showed that $28 \%$ of 25 chicken meat sample contained enrofloksasin residue and $8 \%$ contained ciprofloksasin residue( Widiastuti et al., 2004). Research in DKI Jakarta reported that Neomycin residue in chicken analyzed using ELISA method by Panggabean et al. (2009), was found in $65 \%$ of 136 sample, between $0,1 \mathrm{~s} / \mathrm{d}$ $>10 \mathrm{ppm}$.

Problems due to antibiotic residue in meat are mainly concerned with germ multiresistance to antibiotic that obstruct medication. Broiler feed given by most farmers is commercial feed (complete feed) containing antibiotic which is not thoroughly absorbed in intesitines and mostly secreted in urine or excreta. The objective of this research was therefore to describe broiler farmers' behaviour including knowledge level, attitude and antibiotic practices, and to figure out the types of antibiotic content in broiler feed.

\section{Materials and Methods}

Survey method was applied, aiming at broiler farmers in Pengadegan Municipality, Purbalingga regency conducting feed sampling, both purposive and random method. Sample 
criteria were farmers with broiler production as the main occupation (not a side-job) that were cultivating from day old chick to harvest age (no cage rest), and farmers who were willing to be interview and observation respondents.

Pre-observation result obtained 96 data of total broiler farmers in Pangadegan Municipality, with 2000-10.000 number of broilers. Sampling was determined with Nomogram Harry King, in which sample for $\mathrm{N}=96$ with $90 \%$ confidence level was $34 \%$ of $\mathrm{N}$, therefore the sample was 33 (Sugiyono, 2010). Sampling was conducted at first broiler harvest.

Primary data source comprised interview result and the previously tested questioneron knowledge level, attitude and antibiotic practice. Field trial result, conducted with equal broiler farmer respondent not the real target, was subject to validity test using product moment correlation test between score (value) of each question with questioner total score. Valid statements would further undergo realibility test using SPSS 17.0 for Windows, whose index showed trustability and reliability of the statements.

Data of antibiotic content in feed was analyzed using bioassay, a method using microorganism to detect an active antibiotic compound. The test principle was that antibiotic content in feed would inhibit microorganism growth in agar media which was observable from inhibition around cylindrical paper or cylindrical cup or well agar. The diameter of inhibition showed antibiotic concentration.
The normality of data of knowledge level, attitude and antibiotic practice of broiler farmers, along with result of antibiotic content in broiler feed was subject to software SPSS 17.0 for Windows and descriptive analysis using data tabulation.

\section{Results and Discussion}

\section{Broiler farmers' knowledge, attitude and antibiotic practice}

Measuring farmers' knowledge on antibiotic practice in broiler breeding, dosage and direction of use, knowledge on drug expiry date and risk of antibiotic residue was by calculating total score of correctly answered questionsfrom questioner checklist (Arikunto, 2010). Result of score calculation is presented in Table 1.

Table 1 shows that farmers had good knowledge on the risk of violating antibiotic administration, but less knowledge on dosage and direction and expiry date. They generally assumed drug expiry as the final date drug was given, and did not fully comprehend the actual meaning of expiry date. This was assumedly because farmers lacked of knowledge on proper antibiotic administration given by the competent government officials. All respondents stated that they had never undergone antibiotic extension from the government. Instead, they were more exposed to information and knowledge on antibiotic from partnership personnel (PPL), technical service (TS) from feed or drug producer and poultry shop (PS) who imposed more economic interest to sell their products rather than

Table 1. Distribution of broiler farmers' knowledge on antibiotic practice

\begin{tabular}{lcc}
\hline Knowledge & $\begin{array}{c}\text { Respondent score/Total correct } \\
\text { score }\end{array}$ & $\begin{array}{c}\text { Percentage } \\
\text { (\%) }\end{array}$ \\
\hline Antibiotic benefit & $136 / 198$ & 68.69 \\
Dosage and direction of use & $160 / 264$ & 60.60 \\
Drug expiry date & $14 / 33$ & 42.42 \\
Antibiotic risk & $32 / 33$ & 96.97 \\
\hline
\end{tabular}


sharing proper knowledge on antibiotic use. It was in accordance with Basuno and Yusdja (2009) that farmers improved their knowledge with the guidance of breeding personnel, either from government of private sectors (technical service). Private personnel including poultry shop owners were far more active than government staff. Education and communication were two crucial things to improve in order to increase stockbreeders' knowledge that required collaboration between government staff and technical service. As reported by Alders et al. (2009) that cooperation between field personnel either government staff or technical service in effective communication and information sharing was essential to improve rural farmers knowledge in preventing and controlling HPAI (High Pathogenic Avian Influenza).

Farmers' behavior in administering antibiotic was their opinion to either support or not support the proper antibiotic administration practice in broiler breeding. The behavior included direction of use, dosage calculation and fraction, proper method and time of antibiotic administration, and compliance to drug expiry. Analysis result showed that farmers behavior were generally normal with 28,39 mean value.

Good category showed farmers supporting proper antibiotic administration answered more than $47 \%$ of questioners, while moderate category was $47 \%$ and poor category was less than $47 \%$. The calculation of farmers' behaviour score was by comparison with mean, resulting in scores presented in Table 2. Notoatmodjo (2005) stated that levels of behavior based on intensity are receiving, responding, valuing, and responsible. Survey showed that $51.52 \%$ respondents belonged to poor category. It might be due to receiving or responding level of farmers' behavior in administering antibiotic because their breeding motivation was mainly for maximum benefit to meet daily needs (as occupation); accordingly, farmers tended to violate antibiotic administration rule. Farmers were not convinced that his breeding sustainability was also strongly determined by the breeding product safety. Moreover, this attitude was aggravated by partnership core personnel by offering excessive antibiotic package as if it had been promoted by the government through the loose quality control and animal food product quality.

Farmers were not at the valuing and responsible level in properly administering antibiotic for broiler breeding. This behavior level was in accordance with Sonaiya (2009) that stock breeders possessed low knowledge level in valuing productivity, income and expenses. It was affected by socio-economic factors such as breeding motivation, number of cattle and expenses for feed and health maintenance.

Data on broiler breeding practices were obtained through observation, documentation and recording form of broiler daily maintenance. Good category stated that farmers had conducted more than $50 \%$ of proper antibiotic practice including antibiotic selection based on indication, exact dosage calculation and fraction, administration method and compliance in drug expiry date. Moderate category demonstrated that farmers conducted $50 \%$ practice, while poor category conducted less than $50 \%$. Score calculation was done by comparing the values with the mean, resulting in final scores presented in Table 3.

Table 2. Category of broiler farmers' behaviour in antibiotic practice

\begin{tabular}{lccc}
\hline Category & Score & Total & Percentage (\%) \\
\hline Good & $>28$ & $16 / 33$ & 48.48 \\
Moderate & $=28$ & $0 / 33$ & 0.00 \\
Poor & $<28$ & $17 / 33$ & 51.52 \\
\hline
\end{tabular}


Table 3. Category of broiler farmers' antibiotic practice

\begin{tabular}{lccc}
\hline Category & Score & Total & Percentage (\%) \\
\hline Good & $>5$ & $7 / 33$ & 21.21 \\
Moderate & $=5$ & $11 / 33$ & 33.33 \\
Poor & $<5$ & $15 / 33$ & 45.45 \\
\hline
\end{tabular}

Data above shows that almost half of farmers' antibiotic practice were in moderate category. Notoatmodjo (2005) reported that action or practice would be accomplished by positive attitude toward action and other factors namely facility or infrastructure. Farmers' behavior in proper antibiotic practice at $51.51 \%$ level belonged to poor category.

In broiler production, farmers used antibiotic for several purposes as presented in Table 4. Barton (2000) stated three main functions of antibiotic practice in animal: therapeutic for medicating the sick animals, prophylactic for preventing infection, and growth booster to improve feed and production quality. Types of antibiotic for antistress given through drinking water were Bacitracin, Oxytetracyclin dan Virginiamycin. Dibner and Richards (2005) stated that antibiotic as growth booster had been produced 50 years ago in The United States.

\section{Antibiotic practice as feed additive}

Observation result revealed that all respondents (33/33; 100\%) used complete feed manufactured either at starter period (1-21 days old) or finisher (22 days old - harvest). Detail lists of complete feed is shown in Table 5.

Data in Table 5 show five complete feeds bearing Bacitracin as AGP on the lable used by 18 farmers (54.54\%). Four producers labelled antibiotic positive but did not identify the antibiotic type used by 10 farmers (30.30\%). Two producers did not label AGP additive, used by one farmer (3.03). one producer clearly cited the antibiotic type (Lincomycin) and the content used by two farmers (6.06\%). Many antibiotics used in the animal food-producing industry are poorly adsorbed in the gut of the animal, resulting in as much as $30-90 \%$ of the parent compound being excreted. Antibiotic metabolites can also be bioactive and can be transformed back to the parent compound after excretion. Thus, a significant percentage of the administered antibiotics may be excreted into the environment in active forms (Sarmah et al., 2006).

\section{Antibiotic content in feed}

Laboratory analysis on feed sample reported that $96.97 \%$ (32/33) feeds positively contained antibiotic and $3.03 \%(1 / 33)$ did not. This result emphasized survey by Bahri et al. (2005) that most complete feed in Indonesia (85.7\%) contained antibiotic. Barton (2002) stated that antibiotic practice for feed additive in Australia during 1992-1996 was 55.8\%, different from $15 \%$ in Europe as reported by European Federation of Animal Health (1998) as growth booster, even European Union has banned antibiotic practice as growth booster since 2006.

Table 4. Antibiotic practice in broiler chicken

\begin{tabular}{lcc}
\hline Purposes & User /Total sample & Percentage \\
\hline Anti Stress & $7 / 33$ & 21.21 \\
Disease control & $29 / 33$ & 87.88 \\
Medication & $30 / 33$ & 90.90 \\
\hline
\end{tabular}


Table 5. Manufactured complete feed used in broilers chicken

\begin{tabular}{llcll}
\hline No & \multicolumn{1}{c}{ Feed Code } & Total User & \multicolumn{1}{c}{ Producer } & \multicolumn{1}{c}{ Antibiotic on label } \\
\hline 1 & S12 & 1 & Pokphand, Semarang & Zinc Bacitracin \\
2 & Bro 1 N & 4 & Super Feed, Jombang & + , unidentified \\
3 & 512 B & 1 & Pokphand, Jakarta & Negative \\
4 & BR 1 & 2 & Seta Feed & Virginiamycin, Bacitracin \\
5 & BR 1 & 1 & Panca Patriot Prima & + , unidentified \\
6 & B 101 & 3 & Sierad Feed, Sidoarjo & + , unidentified \\
7 & Broiler Starter & 2 & Cargill, Semarang & Lincomycin 2-4 ppm \\
8 & 510 & 1 & Pokphand, Surabaya & Negative \\
9 & B 11 B & 5 & Pokphand, Semarang & Zinc Bacitracin \\
10 & NP 11 B & 9 & Pokphand, Surabaya & Zinc Bacitracin \\
11 & ASM-P & 2 & Sierad Feed & + , unidentified \\
12 & JS 11 B & 1 & Pokphand Semarang & Zinc Bacitracin \\
13 & 8 202-C & 1 & Malindo, Surabaya & - , unidentified \\
\hline
\end{tabular}

Tabel 6. The content of antibiotics in broiler commercial feed.

\begin{tabular}{lcc}
\hline Type of antibiotic & Positive sample/Total sample & Percentage (\%) \\
\hline Penicillin & $31 / 33$ & 93.94 \\
Kanamycin & $2 / 33$ & 6.06 \\
Erythromycin & $14 / 33$ & 42.42 \\
Oxytetracyclin & $10 / 33$ & 30.30 \\
\hline
\end{tabular}

Feed sampling analysis showed four types of antibiotic not recommended by government (Table 6) namely penicillin, kanamycin, erythromycin dan oxytetracyclin. No producers cited Penicillin as feed additive on the label, although bioassay analysis revealed the opposite in almost all feed (93.94\%). It was probably because the spectrum performance of Bacitracin (antibiotic on the label) was similar to that of Penicillin (Adam, 2002). Mason (2010) reported more than $70 \%$ of antibiotic product in America was administered for cattle feed. Furtula et al. (2010) stated that antibiotic residue in excreta of environment-controlled broiler was similar to that of commercial broiler farm, namely 0.07-66 mg/L depended on the antibiotic type.

Government in Decree of Ministry of Agriculture No. 806 Year 1994 on Animal Medicine Classification recommended antibiotic types as food additive for growth booster as follows: avilamycin (2.5-15 g/ton), avoparcin (7.5-15g/ton), bacitracin Zinc (50 g/ton), enramycin (5-15 g/ton),
flavomycin/Bambermycin (2.5 g/ton), kitasamycin (5-15 g/ton), colistin Sulfate (2-10 $\mathrm{g} /$ ton), lincomycin (2.2-4.4 g/ton), spiramycinembonate (5-20 g/ton) and virginiamycin (5-15 g/ton).The nonrecommended antibiotic for feed caused great concern regarding the long term administration and the long post-expiry date (Oxytetracyclin, 28 days). This indicated violation on AGP administration by feed producers and the weak government control over cattle feed in commerce.

\section{Conclusion}

Farmers had good knowledge on the risk of violating antibiotic proper administration, but low knowledge level on dosage, direction of use and drug expiry date. Most farmers showed moderate attitude and disobeyed the rule of antibiotic administration. Antibiotic was given overdosed as anti-stress and disease control prevention. Antibiotic as growth booster was found in feed. Commercial broiler feed (complete feed) contained four types of 
antibiotic not recommended by government, namely penicillin, kanamycin, erythromycin andoxytetracyclin.

\section{References}

Adam R. 2002. Veterinary Pharmacology and Therapeautics. IOWA State University Press, Ames, lowa.

Alders RG, B Bagnol, E Brum, AS Lubis and MP Young. 2009. Continuing education in the prevention and control of HPAl: A case study on Indonesia. World Poult. Sci. 65(3):529-531.

Arikunto S. 2010. Prosedur Penelitian Suatu Pendekatan Praktik. Rineka Cipta, Jakarta.

Bahri S, E Masbulan and A Kusumaningsih. 2005. Praproduction process as an important factor in producing livestock products for human health. Jurnal Litbang Pertanian. 24(1):27-35. (in Indonesian with abstract in English)

Barton M. 2000. Antibiotic use in animal feed and its impact on human health. Nutrition Res. Reviews.13: 279-299.

Basuno $E$ and $Y$ Yusdja. 2009. The impact of avian influenza outbreak to changes of livestock social capital and rural community in Indonesia. Papers at the National Seminar on Socio-Economic Impact of HPAI Outbreak and Control on SmallScale and Backyard poultry producers in Asia. The Centre of Socio Economic and Policy (PSEKP) in Bogor February 25, 2009. Livestock

Dibner JJ and JD Richards. 2005. Antibiotic growth promoters in agriculture : History and mode of action. Poult. Sci. 84:634-643.

Directorate General of Animal Husbandry and Health. 2011. Livestock and Animal Health Statistics 2011. http://ditjennak.pertanian.go.id/. Accessed on10th March 2011.

Directorate General of Livestock and Veterinary Services. 2013: Livestock and Animal Health Statistics 2013 http://ditjennak.pertanian.go.id/ (accessed: August 30, 2013)

Furtula V, GE Farell, F Diarrasouba, H Rempel, J Prichart and MS Siarra. 2010. Veterinary pharmaceuticals and antibiotic resistance of Escherichia coli isolates in poultry litter from commercials farm and controlled feeding trials. Poult. Sci. 89:180-188.

Indonesian Nutrition Network. 2004. 85\% of broiler meat contains antibiotics. http://www.gizi.net. Accessed February 7, 2011.

Mason T. 2010. Antibiotic overuse in food production animals. J. Med. Law. 6(2):42-45.

Nisha AR. 2008. Antibiotic residues - A global health hazard. Vet. World. 1(12):375-377.

Notoatmodjo S. 2005. Promosi Kesehatan: Teori dan Aplikasi. Rineka Cipta, Jakarta.

Panggabean TA, Inanusantri and E Mardiastuti. 2009, Identification of neomycin residue in chicken meat in Jakarta. Research report. Laboratorium KESMAVET DKI Jakarta, Jakarta. (in Indonesian with abstract in English)

Sarmah AK, MT Meyer, and ABA Boxall. 2006. A global perspective on the use, sales, exposure pathways, occurrence, fate and effects of veterinary antibiotics (VAs) in the environment. Chemosphere, 65:725-759.

Soetisna A. 2010. Withdrawl Time \& Residu Obat Hewan Siapa Peduli ? Infovet. 192:64-66.

Sonaiya EB. 2009. Some technical and socioeconomic factors affecting productivity and profitability of smallholder family poultry. World Poult. Sci. 65(2):201-205.

Sugiyono. 2010. Statistik Untuk Penelitian. Alfabeta, Bandung.

Tajik H, H Malekinejad, SM Razavi-Rouhani, MR Pajouhi, R Mahmoudi, and A Haghnazari. 2010. Chloramphenicol residues in chicken liver, kidney and muscle: A comparison among the antibacterial residues monitoring methods of Four Plate Test, ELISA and HPLC. Food and Chemical Toxicology, 48: 2464-2468.

Widiastuti R, Yuningsih and TB Murdiati. 2004. Enrofloksasin residues in meat and liver of broiler. Proceedings of the Nasional Seminar Animal Husbandry and Veterinary Technology, pp. 515-518.

WSPA. 2010. Antibiotics. The World Society for The Protection Animals (WSPA). London. 